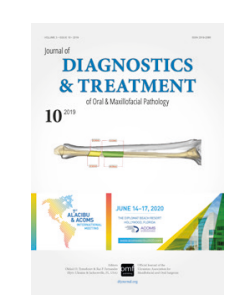

Editorial

\title{
Gold Open Access Journals Focused on Case Reports: Last Trends among Editorial Board Models
}

\author{
Oleksii 0. Tymofieiev \& Evangelos G. Kilipiris ${ }^{b}$
}

Every one of us is, in the cosmic perspective, precious.

If a human disagrees with you, let him live. In a hundred billion galaxies, you will not find another.

-Carl E. Sagan

American astrophysicist and author

Diversity of editorial boards (EBs) composition is as wide as a world number of peer-reviewed journals. EBs usually varies in number of members and their functions, positions, affiliation with different institutions and countries. For example, the EB of International Journal of Oral and Maxillofacial Surgery, a monthly online and print official publication (hybrid publishing model) (2018 impact factor 1.961) of the International Association of Oral and Maxillofacial Surgeons, has 17 editors which represent 9 countries. ${ }^{1}$ Another journal, European Radiology (2018 impact factor 3.962), ${ }^{2}$ a monthly print and online hybrid publication is an official journal of European Society of Radiology, has 196 persons in EB (including 9 members of editorial staff). ${ }^{3}$ These nearly 200 persons represent 27 countires.

The two new trends in a publishing of peerreviewed journals are: 1) gold open access ${ }^{4}$ and 2) case report/case series scope.

\footnotetext{
a Editor in Chief, DTJournal, Kyiv, Ukraine.

E-mail: tymofeev@gmail.com (Oleksii Tymofieiev)

${ }^{\mathrm{b}}$ Director, DTJournal Development Department, Thessaloniki, Greece \& Bratislava, Slovakia

E-mail: varonos@live.co.uk (Evangelos Kilipiris)
}

https://dx.doi.org/10.23999/j.dtomp.2019.10.1.

(C) 2019 OMF Publishing, LLC. This is an open access article under the CC BY license (http://creativecommons.org/licenses/by-nc/4.0/).
Rison et al emphasized that rapidly increasing number of case report journals began in 2007.5 And to the mid-2015 the total number reached 160 journals published by 78 companies.

So, we analyzed the features of a three gold open access and online only publications focused on case reports (Table 1) with no mentioned words "international"/American" in the titles. And the results revealed that in those threejournals (Radiology Case Reports, Oral and Maxillofacial Surgery Cases, and Otolaryngology Case Reports) notes a strong prevalence (mean, 91.95 percent) in EB members' origin from a one country (USA). ${ }^{6-8}$ What may seem contradictory to one of the Scopus "criteria for title (ie journal) selection," which emphasized on a need to have diversity in "geographical distribution of editors." But a successful coverage of Radiology Case Reports and Oral and Maxillofacial Surgery Cases by Scopus indicates that if the journal meets all other 15 criteria $^{9}$ it can be included into Scopus database.

Thus, the answers to databases criteria and peoples' admonition, which tells us that the EB should have geographical diversity, can be the statements of Richardson and Chew (whose journal has all 17 editorial staff's persons (100\%) from USA and is covered by Scopus), that EB members 1) are distinguished faculties, 2) have international editorial experience and reputation, 3) permanent authors in PubMed, Scopus publications and journals with a high impact factor. ${ }^{10}$ To these conclusions we can add that 1) EB members in those 3 journals have a wide network among foreign colleagues who can attract authors with a high quality manuscripts and 2) according to Susarla et al 
TABLE 1. Comparison of Three Gold Open Access Journals Focused on Case Reports.

\begin{tabular}{|l|c|c|c|}
\hline \multicolumn{1}{|c|}{ Criteria } & $\begin{array}{c}\text { Radiology } \\
\text { Case Reports }\end{array}$ & $\begin{array}{c}\text { Oral and Maxillofacial } \\
\text { Surgery Cases }\end{array}$ & $\begin{array}{c}\text { Otolaryngology } \\
\text { Case Reports }\end{array}$ \\
\hline Years (yr) of publishing & $14 \mathrm{yr}$ & $5 \mathrm{yr}$ & $4 \mathrm{yr}$ \\
\hline Covering by PubMed & Yes & No & No \\
\hline Covering by Scopus & Yes & Yes & No \\
\hline Total number of editorial board members and editors & 17 & 17 & 11 \\
\hline Number of persons from the United States, $\%$ & $17(100 \%)$ & $16(93.75 \%)$ & $9(81.82 \%)$ \\
\hline Number of persons from outside of the United States, $\%$ & - & $1(6.25 \%)$ & $2(18.18 \%)$ \\
\hline
\end{tabular}

the ratio between orthognathic surgery studies from North America and international origin is 70 and $30 \%$, respectively. ${ }^{11}$

So, the real restrictions in composition of $\mathrm{EB}$ members (strictly local or international) are usually dictated by two factors: 1 ) journal's title (is there a word "international" or word which depicts some region ["American," etc.]) and 2) official organ/ association/society of the publication (eg the international name of the European Association for Cranio-Maxillo-Facial Surgery led to the need to have international EB composition inside the Journal of Cranio-Maxillo-Facial Surgery). Under other conditions the last trends among gold open access publications focused on case studies are teaching us that EB composition by internationally experienced scientists from one but scientifically strong country or region is also a great option.

\section{REFERENCES}

1. Elsevier: International Journal of Oral and Maxillofacial Surgery: editorial board [document on the internet]; 2019 [cited 2019 Oct 09]. Available from: https://www. journals.elsevier.com/international-journal-of-oraland-maxillofacial-surgery/editorial-board.

2. Springer: European Radiology [document on the internet]; 2019 [cited 2019 Oct 09]. Available from: https://www.springer.com/journal/330.

3. Springer: European Radiology: editors [document on the internet]; 2019 [cited 2019 Oct 10]. Available from: https://www.springer.com/journal/330/editors.
4. van der Heyden MAG, van Veen TAB. Gold open access: the best of both worlds. Neth Heart J 2018;26:34. https://dx.doi.org/10.1007/s12471-017-1064-2.

5. Rison RA, Shepphird JK, Kidd MR. How to choose the best journal for your case report. J Med Case Rep 2017;11:287. https://dx.doi.org/10.1186/s13256-017$1351-\mathrm{y}$.

6. Radiology Case Reports: Editorial Board [document on the internet]; 2019 [cited 2019 Oct 9]. Available from: https://www.journals.elsevier.com/radiologycase-reports/editorial-board.

7. Oral and Maxillofacial Surgery Cases: Editorial Board [document on the internet]; 2019 [cited 2019 Oct 9]. Available from: https://www.journals.elsevier.com/ oral-and-maxillofacial-surgery-cases/editorial-board.

8. Otolaryngology Case Reports: Editorial Board [document on the internet]; 2019 [cited 2019 Oct 9]. Available from: https://www.journals.elsevier.com/ otolaryngology-case-reports/editorial-board.

9. Scopus content coverage guide [document on the internet]; 2019 [cited 2019 Oct 8]. Available from: https://www.elsevier.com/_data/assets/pdf_ file/0007/69451/0597-Scopus-Content-CoverageGuide-US-LETTER-v4-HI-singles-no-ticks.pdf.

10. Richardson ML, Chew FS. Radiology Case Reports: a new peer-reviewed, open-access journal specializing in case reports. Radiol Case Rep 2015;1:1-3. https:// dx.doi.org/10.2484/rcr.vli1.7.

11. Susarla SM, Tveit M, Dodson TB, Kaban LB, Hopper RA, Egbert MA. What are the defining characteristics of the most cited publications in orthognathic surgery? Int J Oral Maxillofac Surg 2018;47:1411-9. https:// dx.doi.org/10.1016/j.ijom.2018.04.016. 